\title{
ANALISIS KESEIMBANGAN LINTASAN UNTUK MENINGKATKAN PROSES PRODUKSI PADA AIR MINERAL DALAM KEMASAN
}

\author{
Harawan Ahyadi, Rudi Saputra,Eko Suhartanto \\ Mahasiswa Program Studi Teknik Industri, FTI-ISTN \\ JI. Moh Kahfi II, Jagakarsa, Jakarta 12640 \\ Email : harwanfti@yahoo.co.id
}

\begin{abstract}
:
Production is an economic activity that adds value by creating and providing goods and services, the creation of products or services and at the same time the creation of value. In economics, production is the act of creating the output, goods or services that have value and contribute to individual utilities. Production line balancing is a very important thing in planning production. Expected to regulate the flow of process efficiency can be achieved optimum production. In addition, the accumulation of intermediate goods from one machine to another machine, thus resulting in increased balance delay. In the process of making drinking water should be done step-by-step production process is handled hygienically, because bottled water products consumed directly by the human body. Drinking water production capacity is 5250 bottles per day, equivalent to 218 boxes, but the target is the company charged, equivalent to 7000 bottles of 291 boxes per day. With the method of determining the regional approach has obtained the standard time of each process for each work station and increase worker productivity, increased production capacities of 218 boxes / day to 295 boxes / day after the repair, companies gain efficiency by 35\%

Kata kunci : Produksi, line balancing
\end{abstract}

\section{PENDAHULUAN}

Keseimbangan lintasan produksi merupakan suatu hal yang sangat penting dalam merencanakan hasil produksi. Diharapkan dengan mengatur aliran proses yang efisiensi dapat dicapai produksi yang optimal. Selain itu adanya penumpukan barang setengah jadi antara satu mesin dengan mesin lainnya, sehingga mengakibatkan meningkatnya balance delay.

Faktor yang terdapat dalam diri manusia; rasa lelah, bosan, sakit pada bagian tubuh tertentu. Hal ini sangat mempengaruhi produktivitas suatu perusahaan, bila hal tersebut tidak diperhatikan maka menyebabkan kurang efisiensinya aliran proses produksi, hingga lintasan produksi menjadi tidak seimbang antara bagian satu dengan bagian lainnya. Kapasitas produksi air mineral dalam kemasan(AMDK) dalam sehari adalah 5250 botol atau setara dengan 218 box, tetapi target yang dibebankan perusahaan adalah 7000 botol atau setara dengan 291 box perhari.
Lintasan produksi yang tidak seimbang akan menimbulkan masalah pada kapasitas produksi jika aliran proses tidak dapat berjalan lancar. Sehingga terjadinya penumpukan bahan baku pada proses filling, labeling, shrinking dan packing, sehingga terlihat terjadi bottle neck yang pada akhirnya mengakibatkan terhambatnya proses produksi

Berdasarkan kondisi tersebut maka penelitian ini dilakukan dengan tujuan:

1. Untuk menentukan waktu baku yang terpakai selama proses produksi AMDK berlangsung.

2. Untuk memperbaiki metode kerja yang selama ini dilakukan.

3. Dapat memperbaiki keseimbangan lintasan dari proses produksi AMDK.

Permasalan yang akan dibahas terfokus pada sasaran adalah sebagai berikut:

1. Penelitian dilakukan di PT. T N F.

2. Waktu kerja yang dipakai dalam satu hari adalah 8 jam. 


\section{TINJAUAN PUSTAKA \\ Pengertian Produksi}

Produksi (Production) adalah kegiatan ekonomi yang memberikan nilai tambah dengan membuat dan menyediakan barang dan jasa, yaitu penciptaan produk atau jasa dan pada saat yang sama yaitu penciptaan nilai. Dalam ilmu ekonomi, produksi merupakan tindakan menciptakan output, barang atau jasa yang memiliki nilai dan berkontribusi terhadap utilitas individu

\section{Pengertian Kapasitas Produksi}

Kapasitas produksi adalah tingkat aktivitas maksimum yang dapat dicapai dengan struktur produksi yang diberikan. Dalam pengertiannnya yang cukup luas dan bersifat umum, sehingga mencakup output yang berupa barang atau jasa

\section{Pengertian Sistem Produksi}

Definisi kata sistem adalah sekelompok elemen yang terintegrasi untuk mencapai suatu tujuan tertentu, sedangkan definisi kata produksi adalah aktivitas untuk menghasilkan barang dan/atau jasa

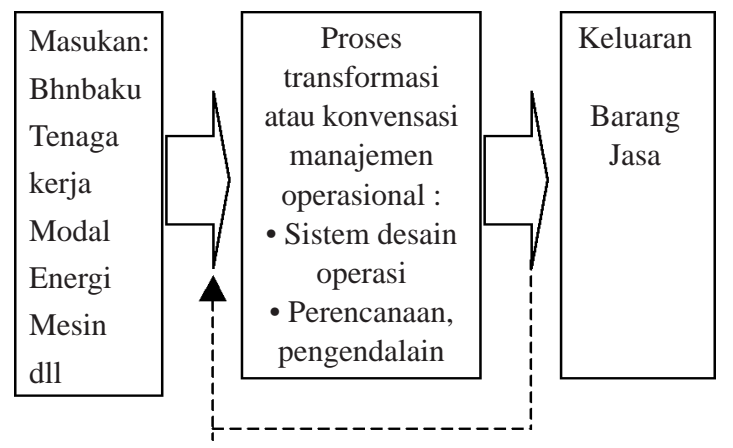

Gambar 2.1: Sistem Produksi Sebagai Proses Transformasi Atau Konversi

\section{Pengertian Produktivitas}

Produktivitas adalah perbandingan antara hasil dari suatu pekerjaan karyawan dengan pengorbanan yang telah dikeluarkan, Sondang P. Siagian bahwa produktivitas adalah: "Kemampuan memperoleh manfaat yang sebesar-besarnya dari sarana dan prasarana yang tersedia dengan menghasilkan output yang optimal bahkan kalau mungkin yang maksimal." Pengertian lain dari produktivitas adalah suatu konsep universal yang menciptakan lebih banyak barang dan jasa bagi kehidupan manusia, dengan menggunakan sumber daya yang serba terbatas (Tarwaka, Bakri, dan Sudiajeng, 2004, p.137).

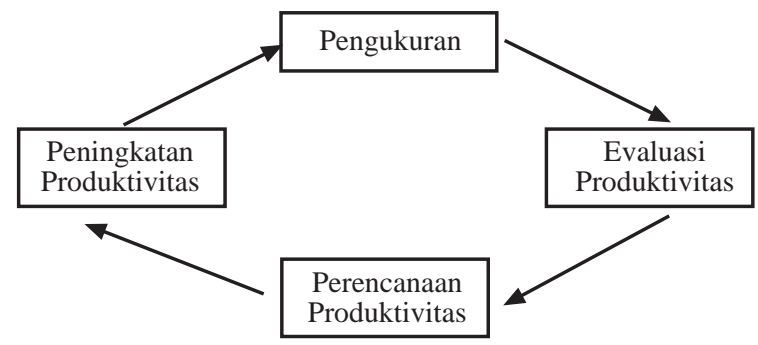

Gambar 2.2 Siklus Produktivitas

\section{Balance Delay}

Balance delay adalah ukuran dari ukuran ketidakefisienan lintasan yang dihasilkan dari waktu menganggur sebenarnya yang disebabkan karma pengalokasian yang kurang sempurna di antara stasiun-stasiun kerja. Keseimbangan waktu senggang (balance delay) dihitung untuk memberikan gambaran apakah telah dicapai keseimbangan lintasan yang baik dengan menggunakan formulasi sebagai berikut :

$$
\mathrm{BD}=\frac{\left(N . t_{c}\right)-\sum t_{i}}{\left(N . t_{c}\right)} \quad \mathrm{X} 100 \%
$$

\section{Keseimbangan Lintasan (Line Balancing)}

Keseimbangan lintasan produksi adalah memaksimumkan efisiensi atau meminimumkan balance delay. Tujuan perencanaan kesimbangan lintasan adalah mendistribusikan unit-unit kerja atau elemen-elemen kerja pada setiap stasiun kerja agar waktu menganggur dari stasiun kerja pada suatu lintasan produksi dapat ditekan seminimal mungkin, sehingga pemanfaatan dari peralatan maupun operator dapat digunakan semaksimal mungkin.

Langkah-langkah dalam keseimbangan lintasan :

1. Tentukan hubungan antara pekerjaan yang terlihat dalam suatu lintasan produksi dan hubungan antara pekerjaan tersebut digambarkan dalam precedence diagram.

2. Menentukan waktu siklus yang dibutuhkan dengan menggunakan rumus:

$$
\begin{gathered}
\mathrm{CT}=\text { Production Time per }- \text { hari } \\
\text { Output per }- \text { hari }
\end{gathered}
$$

Dimana: $\mathrm{CT}=$ Cyclus Time (waktu siklus )

3. Menentukan jumlah minimum stasiun kerja teoritis yang dibutuhkan untuk memenuhi pembatas waktu siklus dengan menggunakan rumus :

Jumlah Total dari Waktu Pekerjaan setiap elemen Waktu Siklus

4. Pilih metode untuk melakukan penyeimbangan 
lintasan.

5. Menghitung efisiensi lintasan, efisiensi stasiun kerja, waktu menganggur dan balance delay berdasarkan metode yang dipilih untuk melihat performansi keseimbangan lintasan produksi.

6. Menghitung kapasitas produksi yang dihasilkan dan produktivitas pekerja.

\section{Faktor-Faktor yang Mempengaruhi Keseim- bangan Lintasan}

Faktor-faktor yang mempengaruhi keseimbangan lintasan antara lain:

1. Terlambatnya bahan baku

2. Material handling yang kurang sempuma

3. Terjadinya kerusakan mesin

4. Bertumpuknya barang dalam proses pada tingkat proses tertentu

5. Kondisi mesin yang sudah tua

6. Kelemahan dalarn merencanakan kapasitas mesin

7. Lay out yang kurang baik

8. Kualitas tenaga kerja yang kurang baik

9. Adanya working condition yang kurang baik

\section{Metode Pendekatan Wilayah}

Metode ini dikembangkan oleh Bedworth untuk mengatasi kekurangan metode bobot posisi. Bedworth menyebutkan bahwa kegagalan metode bobot posisi ialah mendahulukan operasi dengan waktu operasi terbesar daripada operasi dengan waktu operasi yang tidak terlalu besar, tetapi diikuti oleh banyak operasi lainnya.

\section{Penyesuaian (Rating Performance Kerja)}

Penyesuaian adalah waktu untuk mengetahui kecepatan atau tempo kerja operator yang dilihat dari berbagai macam segi yaitu keterampilan, usaha, kondisi kerja, konsistensi pada saat pengukuran kerja berlangsung. (Wignjasoebroto, 1992)

Tabe1 2.2. Penyesuaian menurut Shumard

\begin{tabular}{|l|c|l|c|}
\hline Kelas & $\begin{array}{c}\text { Penye } \\
\text { suaian }\end{array}$ & Kelas & $\begin{array}{c}\text { Penye } \\
\text { suaian }\end{array}$ \\
\hline Superfast & 100 & Good - & 65 \\
Fast + & 95 & Normal & 60 \\
Fast & 90 & Fair + & 55 \\
Fast - & 85 & Fair & 50 \\
Excellent & 80 & Fair & 45 \\
Good + & 75 & Poor & 40 \\
Good & 70 & & \\
\hline
\end{tabular}

\section{Pengukuran Waktu Kerja (Time Study atau Work Measurement)}

Time study atau work measurement adalah suatu kumpulan dan cara-cara yang dipergunakan untuk menentukan waktu yang diperlukan oleh seorang pekerja yang sudah terampil (qualified) yang beker ja secara normal untuk menyelesaikan pekerjaannya.

Pengertian umum pengukuran kerja adalah suatu aktivitas untuk menentukan waktu yang dibutuhkan oleh seorang operator (yang memiliki skil keahlian rata-rata dan terlatih) dalam melaksanakan kegiatan kerja.

Tabel 2.1 Pengelompokan Sub group Stasiun Kerja Waktu Penyelesaian

\begin{tabular}{|c|c|c|}
\hline $\begin{array}{c}\text { Stasium } \\
\text { Kerja }\end{array}$ & $\begin{array}{c}\text { Waktu Penyelesaian } \\
\mathrm{x}_{\mathrm{ij}}\end{array}$ & $\begin{array}{c}\text { Rata-Rata } \\
\text { Sub group } \\
\bar{x}_{\mathbf{i}}\end{array}$ \\
\hline 1 & $\mathrm{x}_{11}+\mathrm{x}_{12}+\ldots \ldots \mathrm{x}_{1 \mathrm{n}}$ & $\bar{X}_{1 \mathrm{n}}$ \\
\hline 2 & $\mathrm{x}_{21}+\mathrm{x}_{22}+\ldots \ldots \mathrm{x}_{2 \mathrm{n}}$ & $\bar{X}_{2 \mathrm{n}}$ \\
\hline 3 & $\mathrm{x}_{\mathrm{x} 1}+\mathrm{x}_{\mathrm{x} 2}+\ldots \ldots \mathrm{x}_{\mathrm{xn}}$ & $\bar{X}_{3 \mathrm{n}}$ \\
\hline \multicolumn{2}{|l}{} & $\sum \bar{X}_{\mathrm{i}}$ \\
\hline
\end{tabular}

Langkah pengukuran waktu kerja gambar 2.3

\section{LANGKAH PERSIAPAN}

Pilih dan definiskan pekerjaan yang akan diukur dan yang akan diterapkan waltu standarnya Informasikan maksud dan tujuan pengukuran kerja kepada operator atau pekerja

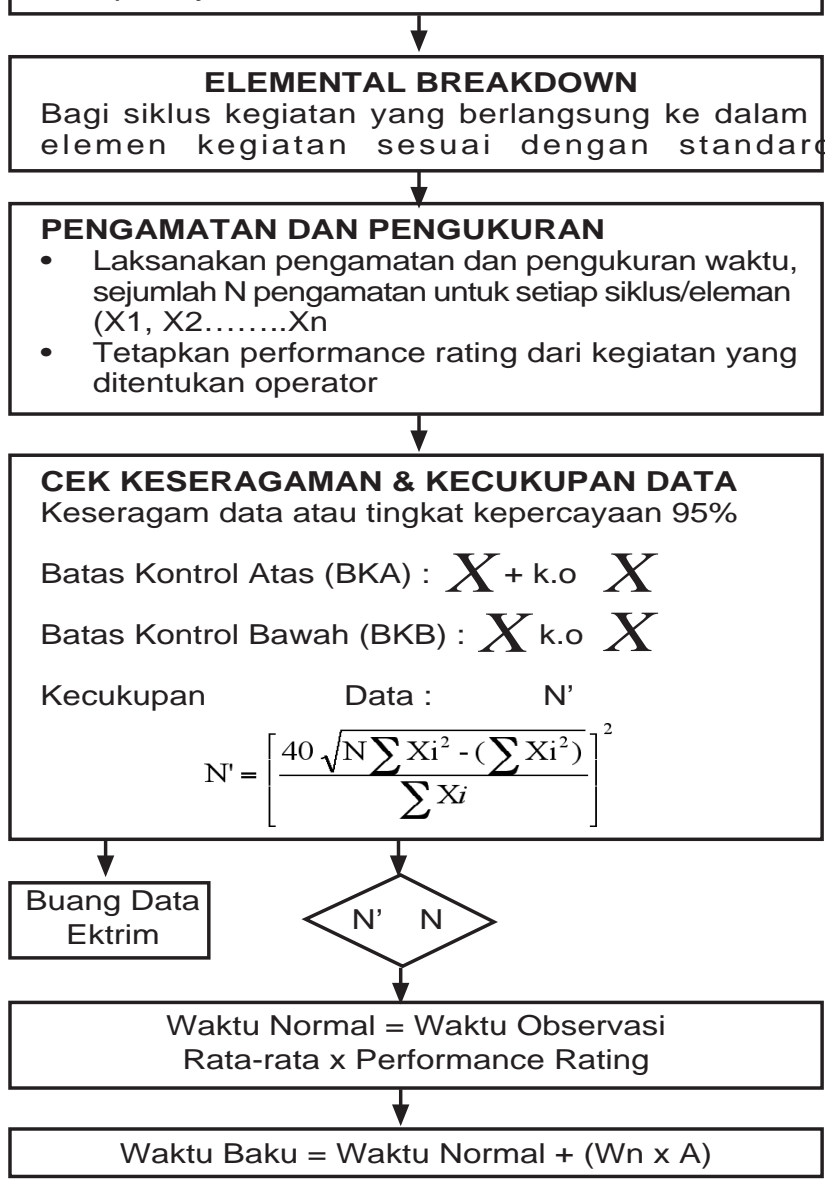


Tabe1 2.3. Penyesuaian menurut Westinghouse

\begin{tabular}{|c|c|c|c|}
\hline Faktor & Kelas & Lambang & Penyesuian \\
\hline \multirow{11}{*}{ Ketrampilan } & Superskill & $\bar{A} 1$ & $+0,15$ \\
\hline & & $\mathrm{A} 2$ & $+0,13$ \\
\hline & Excellent & B 1 & $+0,11$ \\
\hline & & B2 & $+0,08$ \\
\hline & Good & C 1 & $+0,06$ \\
\hline & & $\mathrm{C} 2$ & $+0,03$ \\
\hline & Average & $\mathrm{D}$ & 0,00 \\
\hline & Fair & E 1 & $-0,05$ \\
\hline & & $\mathrm{E} 2$ & $-0,10$ \\
\hline & Poor & F 1 & $-0,16$ \\
\hline & & $\mathrm{F} 2$ & $-0,22$ \\
\hline Faktor & Kelas & Lambang & Penyesuian \\
\hline \multirow{11}{*}{ Usaha } & Excessive & A1 & $+0,13$ \\
\hline & & $\mathrm{A} 2$ & $+0,12$ \\
\hline & Excellent & B 1 & $+0,10$ \\
\hline & & $\mathrm{B} 2$ & $+0,08$ \\
\hline & Good & $\mathrm{C} 1$ & $+0,05$ \\
\hline & & $\mathrm{C} 2$ & $+0,02$ \\
\hline & Average & $\mathrm{D}$ & 0,00 \\
\hline & Fair & E 1 & $-0,04$ \\
\hline & & $\mathrm{E} 2$ & $-0,08$ \\
\hline & Poor & F 1 & $-0,12$ \\
\hline & & $\mathrm{F} 2$ & $-0,17$ \\
\hline Faktor & Kelas & Lambang & Penyesuian \\
\hline \multirow{6}{*}{ Kondisi Kerja } & Ideal & $\mathrm{A}$ & $+0,06$ \\
\hline & Excellent & B & $+0,04$ \\
\hline & Good & $\mathrm{C}$ & $+0,02$ \\
\hline & Average & $\mathrm{D}$ & 0,00 \\
\hline & Fair & $\mathrm{E}$ & $-0,03$ \\
\hline & Poor & $\mathrm{F}$ & $-0,07$ \\
\hline Faktor & Kelas & Lambang & Penyesuian \\
\hline \multirow{6}{*}{ Konsistensi } & Perfecct & $\bar{A}$ & $+0,04$ \\
\hline & Excellent & B & $+0,03$ \\
\hline & Good & $\mathrm{C}$ & $+0_{1}, 01$ \\
\hline & Average & $\mathrm{D}$ & 0,00 \\
\hline & Fair & $\mathrm{E}$ & $-0,02$ \\
\hline & Poor & $\mathrm{F}$ & $-0,04$ \\
\hline
\end{tabular}

\section{Kelonggaran (Allowance)}

Kelonggaran adalah waktu yang diberikan pada seseorang, dalarn waktu melakukan pekerj aan yaitu kelonggaran untuk waktu kebutuhan pribadi, kelonggaran untuk menghilangkan rasa fatique atau lelah, kelonggaran untuk hambatanhambatan tak terhindarkan (Sutalaksana,1979).

\begin{tabular}{|c|c|c|c|c|}
\hline \multirow[t]{2}{*}{ Faktor } & \multirow{2}{*}{$\begin{array}{l}\text { Contoh } \\
\text { Pekerjaan }\end{array}$} & \multicolumn{3}{|c|}{ Kelonggaran (\%) } \\
\hline & & $\begin{array}{l}\text { Ekivalen } \\
\text { beban }\end{array}$ & Pria & Wanita \\
\hline $\begin{array}{l}\text { A. Tenaga } \\
\text { dikeluarkan }\end{array}$ & & & & \\
\hline $\begin{array}{l}\text { 1. Dapat } \\
\text { kebaikan }\end{array}$ & $\begin{array}{l}\text { Bekerja } \\
\text { dimeja, } \\
\text { duduk } \\
\text { Bekerja }\end{array}$ & tanpa beban & $0.0-6.0$ & $0.0-6.0$ \\
\hline $\begin{array}{l}\text { 2. Sangat } \\
\text { ringan }\end{array}$ & dimeja, & $0.00-2,25 \mathrm{~kg}$ & $6.0-7.5$ & $6.0-7.5$ \\
\hline 3. Ringan & $\begin{array}{l}\text { Menyekap, } \\
\text { ringan }\end{array}$ & $2.25-9.00$ & $7.5-12.0$ & $\begin{array}{l}7.5-16.0 \\
16.0-30.0\end{array}$ \\
\hline 4. Sedang & $\begin{array}{l}\text { Mencangkul } \\
\text { Mengayun } \\
\text { palu yang }\end{array}$ & $9.00-18.00$ & $12.0-19.0$ & \\
\hline $\begin{array}{l}\text { 5. Berat } \\
6 \text {. Sangat } \\
\text { berat }\end{array}$ & $\begin{array}{l}\text { berat } \\
\text { Memanggul } \\
\text { beban }\end{array}$ & $19.00-27.00$ & $19.0-30.0$ & \\
\hline
\end{tabular}

\begin{tabular}{|c|c|c|c|c|}
\hline \multirow[t]{2}{*}{ Faktor } & \multirow{2}{*}{$\begin{array}{l}\text { Contoh } \\
\text { Pekerjaan }\end{array}$} & \multicolumn{3}{|c|}{ Kelonggaran (\%) } \\
\hline & & $\begin{array}{l}\text { Ekivalen } \\
\text { beban }\end{array}$ & Pria & Wanita \\
\hline \multicolumn{5}{|l|}{$\begin{array}{l}\text { B. Sikap } \\
\text { bekerja }\end{array}$} \\
\hline & $\begin{array}{l}\text { Bekerja } \\
\text { duduk, }\end{array}$ & & $0.00-$ & \\
\hline 1. Duduk & ringan & & 1.00 & \\
\hline 2. Berdiri & Badan tegak & & & \\
\hline diatas dua & ditompa dua & & $1.00-$ & \\
\hline kaki & kaki & & 2.50 & \\
\hline 3. berdiri & Satu kaki & & & \\
\hline diatas satu & mengerjakan & & $2.50-$ & \\
\hline kaki & $\begin{array}{l}\text { alat kontrol } \\
\text { Pada bagian } \\
\text { sisi, }\end{array}$ & & 4.00 & \\
\hline 4. Berbaring & $\begin{array}{l}\text { belakang } \\
\text { atau depan }\end{array}$ & & $\begin{array}{c}2.50- \\
4.00\end{array}$ & \\
\hline & $\begin{array}{l}\text { Badan } \\
\text { dibungkukan } \\
\text { bertumpu }\end{array}$ & & & \\
\hline 5. & pada dua & & $4.00-$ & \\
\hline Membungkuk & kaki & & 10.00 & \\
\hline
\end{tabular}

\begin{tabular}{|c|c|c|c|c|}
\hline \multirow[t]{2}{*}{ Faktor } & \multirow{2}{*}{$\begin{array}{l}\text { Contoh } \\
\text { Pekerjaan }\end{array}$} & \multicolumn{3}{|c|}{ Kelonggaran (\%) } \\
\hline & & $\begin{array}{l}\text { Ekivalen } \\
\text { beban }\end{array}$ & Pria & Wanita \\
\hline \multicolumn{5}{|l|}{$\begin{array}{l}\text { C. } \\
\text { Gerakan } \\
\text { kerja }\end{array}$} \\
\hline & $\begin{array}{l}\text { Ayunan } \\
\text { bebas dari }\end{array}$ & & & \\
\hline 1.Normal & peta & & 0 & \\
\hline 2. Agak & $\begin{array}{l}\text { Ayunan } \\
\text { terbatas dari }\end{array}$ & & & \\
\hline terbatas & $\begin{array}{l}\text { peta } \\
\text { Membawa } \\
\text { beban berat } \\
\text { dengan satu }\end{array}$ & & $0.0-5.0$ & \\
\hline 3. Sulit & $\begin{array}{l}\text { lengan } \\
\text { Bekerja }\end{array}$ & & $0.0-5.0$ & \\
\hline $\begin{array}{l}\text { 4. Pada } \\
\text { anggota }\end{array}$ & $\begin{array}{l}\text { dengan } \\
\text { lengan }\end{array}$ & & & \\
\hline badan & diatas & & $5.0-$ & \\
\hline $\begin{array}{l}\text { terbatas } \\
5 .\end{array}$ & kepala & & 10.0 & \\
\hline $\begin{array}{l}\text { Seluruh } \\
\text { anggota }\end{array}$ & $\begin{array}{l}\text { Bekerja } \\
\text { dilorong }\end{array}$ & & & \\
\hline badan & tambang & & $10.0-$ & \\
\hline terbatas & yang sempit & & 15.0 & \\
\hline
\end{tabular}

\begin{tabular}{llll}
\hline Faktor & $\begin{array}{l}\text { Contoh } \\
\text { Pekerjaan }\end{array}$ & $\begin{array}{l}\text { Ekivalen } \\
\text { beban }\end{array}$ & Pria \\
\hline E
\end{tabular}

Keadaan

temperatur

\begin{tabular}{|c|c|c|c|}
\hline $\begin{array}{l}\text { tempat } \\
\text { kerja }\end{array}$ & $\begin{array}{c}\text { Temperatur } \\
(0 \mathrm{c})\end{array}$ & $\begin{array}{c}\text { Keadaan } \\
\text { normal } \\
\text { diatas }\end{array}$ & Berlebihan \\
\hline 1. Beku & diatas 10 & 10.0 & diatas 12.0 \\
\hline 2. Rendah & $0.0-13.0$ & $10.0-0.0$ & $12.0-0.0$ \\
\hline 3. Sedang & $13.0-22.0$ & $3.0-0.0$ & $8.0-0.0$ \\
\hline 4. Normal & $22.0-28.0$ & $0.0-5.0$ & $0.0-8.0$ \\
\hline 5. Tinggi & $28.0-38.0$ & $3.0-40.0$ & $8.0-100.0$ \\
\hline
\end{tabular}




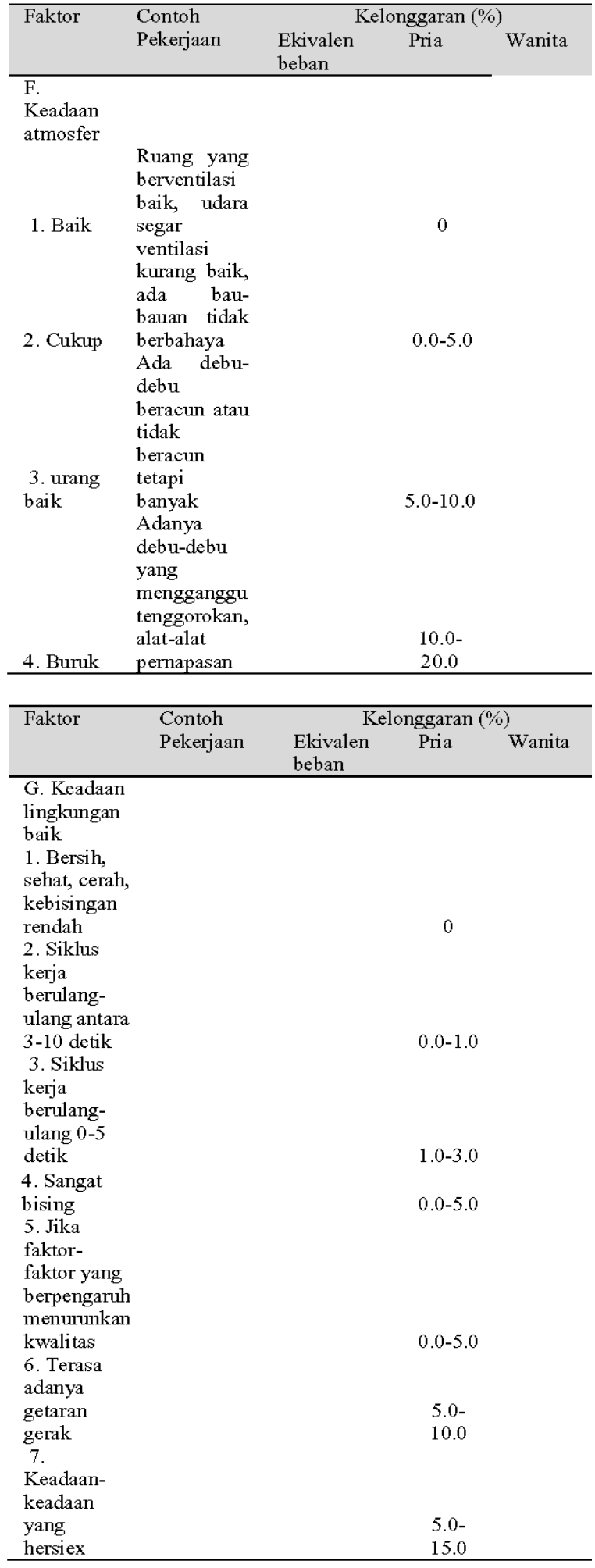

\section{Macam-macam Peta Kerja}

Pada dasarnya peta-peta kerja yang ada sekarang ini dibagi dalam dua kelompok besar berdasarkan kegiatannya, yaitu:

1. Peta-peta kerja ynag digunakan untuk menganalisis kegiatan secara keseluruhan

2. Peta-peta kerja yang digunakan untuk mengalisis kegiatan setempat
Peta Proses Operasi (Operation Process Chart)

Teknik ini terutama untuk melihat operasi mandiri dari tiap komponen atau rakitan. Peta ini akan memberikan gambaran yang lebih cermat tentang pola aliran produksi dibanding dengan peta rakitan karena peta ini menambahkan data kuantitatif pertama pada usulan perencanaan aliran.

Peta proses operasi adalah salah satu teknik yang paling berguna dalam perencanaan produksi. Kenyataannya, peta ini adalah diagram tentang proses dan telah digunakan dalam berbagai cara sebagai alat perencanaan dan pengendalian. Dengan tambahan data lain, peta ini dapat digunakan sebagai alat manajemen.

Untuk keperluan pembuatan peta proses ini maka oleh American Society of Mechanical Engineers (ASME) telah dibuat beberapa symbol standard yang menggambarkan macam jenis aktivitas yang umum dijumpai dalam proses produksi, yaitu pada table 2.5 sebagai berikut :

Tabel 2.5. Simbol-simbol yang Dipergunakan Dalam Pembuatan Proses (ASME Standart)

Sumber: (Wignjosoebroto, 2003)

\begin{tabular}{|c|c|c|}
\hline $\begin{array}{l}\text { Simbol } \\
\text { ASME }\end{array}$ & $\begin{array}{l}\text { Nama } \\
\text { Kegiatan }\end{array}$ & Difinisi Kegiatan \\
\hline & Operasi & $\begin{array}{l}\text { Kegiatan operasi terjadi } \\
\text { bilama sebuah objek (benda } \\
\text { kerja/bahan baku) } \\
\text { mengalamai perubahan } \\
\text { bentuk baik secara fisik } \\
\text { maupun kimiawi, perakitan } \\
\text { dengan objek lainnya atau } \\
\text { dirakit, dan lain-lain }\end{array}$ \\
\hline & Inspeksi & $\begin{array}{l}\text { Kegiatan inspeksi terjadi } \\
\text { bilama sebuah objek } \\
\text { mengalami pengujian } \\
\text { ataupun pengecekan ditinjau } \\
\text { dari segi kualitas ataupun } \\
\text { kuantitas }\end{array}$ \\
\hline & Transportasi & $\begin{array}{l}\text { Kegiatan transportasi terjadi } \\
\text { bilama sebuah objek } \\
\text { dipindahkan dari satu lokasi } \\
\text { ke lokasi yang lain, bilamana } \\
\text { gerakan perpindahan } \\
\text { tersebut merupakan bagian } \\
\text { dari operasi/inspeksi seoerti } \\
\text { halnya dengan loading } \\
\text { unloading material maka hal } \\
\text { tersebut bukan termasuk } \\
\text { kegiatantransportasi }\end{array}$ \\
\hline & $\begin{array}{l}\text { Menuggu } \\
\text { (Delay }\end{array}$ & $\begin{array}{l}\text { Proses menunggu terjadi bila } \\
\text { material benda kerja, } \\
\text { operator atau fasilitas kerja } \\
\text { dalam keadaan berhenti atau } \\
\text { tidak mengalami kegiatan } \\
\text { apaupun. Biasanya obyek } \\
\text { terpaksa menunggu atau } \\
\text { ditinggalkan semetara sampai } \\
\text { suatu } \\
\text { dikerjakan/diperlukan } \\
\text { kembali. }\end{array}$ \\
\hline
\end{tabular}




\section{METODE PENELITIAN}

\section{Waktu dan Lokasi Penelitian}

Lokasi pengumpulan data untuk penyusunan tugas akhir ini dilakukan pada PT. TNF yang terletak di Kawasan Industri Pulogadung No. 75 Jakarta

\section{Identifikasi Variabel}

Variable-variabel yang digunakan dalam permasalahan yang sedang diteliti adalah sebagai berikut :

- Variabel Terikat

- Variabel Bebas

\section{Metode Pengumpulan Data}

Library Research (Studi Kepustakaan)

Field Research (Studi Lapangan)

\section{Metode Analisis Data}

Setelah data yang diperlukan telah diperoleh dari pengamatan kemudian dilakukan analisis dengan line balancing meliputi waktu proses, perhitungan kemampuan produksi tiap-tiap stasiun kerja dan perhitungan jumlah karyawan. Adapun langkah-langkahnya adalah sebagai berikut:

1. Pengolahan dan pengukuran waktu beban kerja

2. Perhitungan output standard

3. Menentukan model keseimbangan lintasan

4. Melakukan perbandingan kondisi usulan dengan kondisi awal

\section{Langkah-langkah Pemecahan Masalah}

Flow Chart penyelesaian masalah :

1. Rumusan masalah

Pada penelitian ini dirumuskan suatu masalah yaitu :

"Bagaimana upaya yang dilakukan untuk menyeimbangkan lintasan produksi agar tercapai target produksi yang diinginkan”. Sebelum merumus-kan suatu masalah, dilakukan studi lapangan dan studi pustaka terlebih dahulu.

2. Tujuan Penelitian

Pada langkah ini peneliti menetapkan tujuan yang dingin dicapai melalui penelitian. Dari tujuan penelitian dapat ditemukan arah serta sasaran yang ingin dicapai dalam penelitian. Tujuan pene-litian ini diuraikan dalam bab I.

3. Pengumpulan Data

Mengumpulkan data-data pada proses produksi, meliputi pengukuran waktu produksi dan output produksi.

4. Uji keseragaman data

Melakukan pengujian data waktu proses produksi, jika data seragam (data-data yang berada didalam batas kontrol atas dan batas kontrol bawah) langsung ke pengujian uji kecukupan data. Jika tidak, buang data yang ekstrim kemu-dian ke pengujian kecukupan data.

5. Uji kecukupan data

Melakukan pengujian data waktu proses produksi, jika data cukup langsung menghitung WS, WN, dan WB. Jika tidak melakukan pengumpulan data ulang.

6. Menghitung WS, WN, dan WB.

7. Dari WB dihitung keseimbangan lintasan awal dan lintasan dengan metode usulan. Jika kondisi awal lebih kecil dari kondisi usulan maka pilih metode usulan, dan jika kondisi awal lebih baik dari usulan maka langsung ke pem-bahasan.

8. Analisa dan pembahasan

Lakukan pembahasan terhadap hasil dari penelitian yang dilakukan.

9. Kesimpulan dan saran

Memberikan kesimpulan dari hasil penelitian yang dilakukan dan mem-berikan saran yang berguna bagi perusahaan.

10. Selesai

\section{DATA DAN PEMBAHASAN \\ Pengumpulan Data}

Dari pengamatan yang dilakukan pada proses produksi AMDK, didapat hasil pengamatan diarea produksi sebagai berikut.

Tenaga Kerja

$\begin{array}{ll}\text { Stasiun } 1=3 \text { orang } & \text { Stasiun } 6=6 \text { orang } \\ \text { Stasiun } 2=4 \text { orang } & \text { Stasiun } 7=2 \text { orang } \\ \text { Stasiun } 3=2 \text { orang } & \text { Stasiun } 8=3 \text { orang } \\ \text { Stasiun } 4=3 \text { orang } & \text { Stasiun } 9=3 \text { orang } \\ \text { Stasiun } 5=4 \text { orang } & \end{array}$

\section{Waktu Kerja Perusahaan}

Waktu kerja yang berlaku di PT. TNF pada proses air mineral dalam kemasan (AMDK) dalam seminggu ada 5 hari kerja

Proses Produksi air mineral dalam kemasan (AMDK)

Proses produksi AMDK di PT. TNF 
merupakan proses yang continue (terus-menerus). Proses tersebut terdiri dari proses secara manual maupun menggunakan mesin dan conveyor. Proses produksi AMDK pada PT. TNF telah dibagi menjadi 9 stasiun

\section{Tingkat Produksi Harian}

Pada saat penelitian dilakukan target produksi AMDK adalah 218 box/ hari adapun 1 box sebanyak 24 botol (sumber production department AMDK-PT.TNF) sedangkan tingkat rata-rata hasil produksi harian dari bulan Januari 2013 s/d Juni 2013 didapat dari perhitungan sebagai berikut:

$$
\begin{aligned}
& \text { Rata-rata hasil produksi }=\frac{\Sigma x_{i j}}{n} \\
& \frac{218.59+218.22+218.31+218.12+218.06+218.05}{6} \\
& =218.22 \approx 218 \text { box / hari }
\end{aligned}
$$

\begin{tabular}{|c|c|c|}
\hline $\begin{array}{c}\text { Stasiun } \\
\text { Kerja }\end{array}$ & $\begin{array}{c}\text { No } \\
\text { Operasi }\end{array}$ & Keterangan Operasi \\
\hline I & $0-1$ & $\begin{array}{l}\text { Sortir botol yang akan diproses pada } \\
\text { produksi AMDK. }\end{array}$ \\
\hline \multirow{3}{*}{ II } & $0-2$ & $\begin{array}{l}\text { Menyiapkan botol pada mesin washing } \\
\text { bottle }\end{array}$ \\
\hline & $0-3$ & $\begin{array}{l}\text { Menyusun botol yang telah disortir } \\
\text { kemesin washing untuk dicuci. }\end{array}$ \\
\hline & $0-4$ & $\begin{array}{l}\text { Menyusun botol yang sudah dicuci ke } \\
\text { atas tray. }\end{array}$ \\
\hline III & $0-5$ & $\begin{array}{l}\text { Memindahkan tray-tray botol yang } \\
\text { sudah bersih ke ruang filling }\end{array}$ \\
\hline \multirow{3}{*}{ IV } & $0-6$ & $\begin{array}{l}\text { Menyusun botol yang akan di filling } \\
\text { pada filling machine }\end{array}$ \\
\hline & $0-7$ & Filling botol \\
\hline & $0-8$ & Memasang cup botol \\
\hline V & $0-9$ & Inspection \\
\hline \multirow{2}{*}{ Vl } & $0-10$ & Memasang label \\
\hline & $0-11$ & Memasang cup seal \\
\hline VII & $0-12$ & $\begin{array}{l}\text { Memindahkan botol yang telah diberi } \\
\text { cup dan label kemeja }\end{array}$ \\
\hline VIII & $0-13$ & $\begin{array}{l}\text { Inspection membenarkan posisi label } \\
\text { dan menaruh botol diatas conveyor } \\
\text { srhingking (pemanasan label) }\end{array}$ \\
\hline \multirow{3}{*}{ IX } & $0-14$ & Packing botol ke box@24pcs \\
\hline & $0-15$ & $\begin{array}{l}\text { Menimbang dan mencatat bobot master } \\
\text { box }\end{array}$ \\
\hline & $0-16$ & $\begin{array}{l}\text { Menaruh masterbox yang telah } \\
\text { ditimbang diatas palet }\end{array}$ \\
\hline
\end{tabular}

\section{Pengolahan Data}

\section{Pengukuran Waktu Kerja}

Pengukuran waktu adalah metode untuk mencapai ketepatan data yang berguna dalam perbaikan dan pengontrolan kerja melalui waktu kerja yang dihasilkan oleh operator

\section{Pengamatan Pendahuluan}

Pada tahap ini pengumpulan dan pengolahan data dilakukan berdasarkan pengukuran pendahuluan tahap pertama yang dilakukan pada proses produksi AMDK

\section{Uji Keseragaman Data}

Tujuan mengukur waktu kerja adalah untuk mendapatkan data yang seragam. Karena keseragaman yang dapat "mendeteksi" batas-batas control yang dibentuk dari data merupakan batas

\begin{tabular}{|c|c|c|c|c|c|c|}
\hline \multirow{2}{*}{ Sub Group } & \multicolumn{5}{|c|}{ Waktu Penyelesaian (detik) } & \multirow{2}{*}{ Rata-Rata } \\
\hline & 1 & 2 & 3 & 4 & 5 & \\
\hline & & & & & & Sub Group \\
\hline 1 & 42 & 42 & 40 & 44 & 42 & 42 \\
\hline 2 & 45 & 43 & 42 & 43 & 44 & 43,4 \\
\hline 3 & 41 & 43 & 42 & 43 & 45 & 42,8 \\
\hline 4 & 42 & 42 & 45 & 44 & 42 & 43 \\
\hline \multicolumn{6}{|c|}{ Jumlah } & 171,2 \\
\hline
\end{tabular}
seragam tidaknya data.

Tabel 4.3 Waktu Proses Sortir

Tabel 4.4 Perhitungan Standar Deviasi Operasi 1

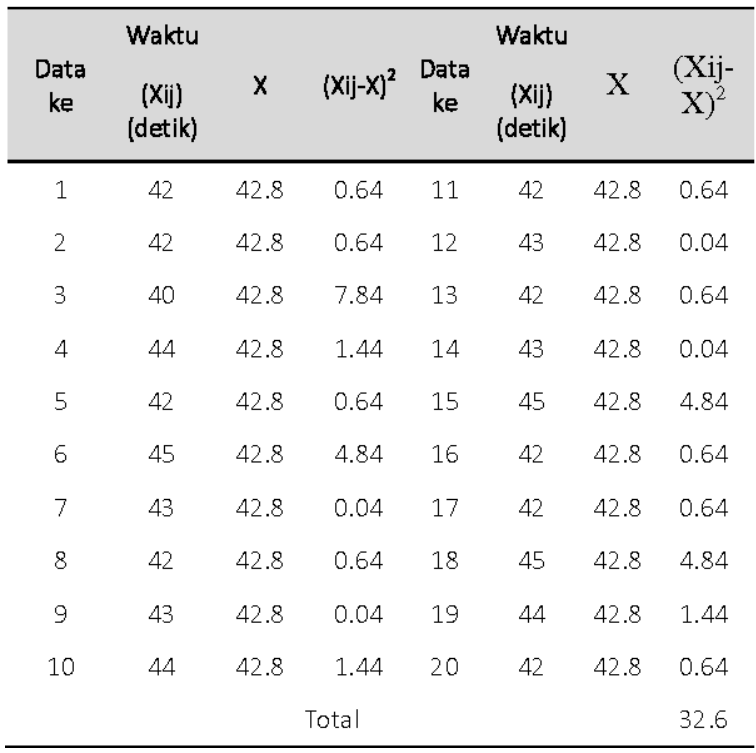

\section{Uji Kecukupan Data}

Uji kecukupan data dilakukan untuk mendapatkan tingkat ketelitian dan tingkat keyakinan yang merupakan pencerminan tingkat kepastian yang diinginkan oleh pengukur setelah memutuskan tidak akan melakukan pengukuran yang sangat banyak karena data sudah mencukupi. 
Tabel 4.5. Perhitungan Untuk Kecukupan Data

\begin{tabular}{cccccc}
\hline $\begin{array}{c}\text { Data } \\
\text { Ke }\end{array}$ & $\begin{array}{c}\text { Waktu } \\
(\text { Xij }) \\
\text { (detik) }\end{array}$ & $\begin{array}{c}\text { (Xij)2 } \\
\text { ke }\end{array}$ & $\begin{array}{c}\text { Data } \\
\text { Waktu } \\
(\text { Xij }) \\
\text { (detik) }\end{array}$ & (Xij)2 \\
\hline 1 & 42 & 1764 & 11 & 42 & 1764 \\
2 & 42 & 1764 & 12 & 43 & 1849 \\
3 & 40 & 1600 & 13 & 42 & 1764 \\
4 & 44 & 1936 & 14 & 43 & 1849 \\
5 & 42 & 1764 & 15 & 45 & 2025 \\
6 & 45 & 2025 & 16 & 42 & 1764 \\
7 & 43 & 1849 & 17 & 42 & 1764 \\
8 & 42 & 1764 & 18 & 45 & 2025 \\
9 & 43 & 1849 & 19 & 44 & 1936 \\
10 & 44 & 1936 & 20 & 42 & 1764 \\
& & & & 857 & 36755 \\
\hline
\end{tabular}

\section{Menghitung Waktu Siklus}

Waktu siklus merupakan rata-rata dari pengukuran waktu kerja yang dilakukan tiap operasi.

$$
\mathrm{Ws}=\frac{\sum \bar{X}}{L}=\frac{171.2}{4}=42.8 \text { detik }
$$

\section{Menghitung Waktu Normal}

Aktivitas untuk menilai atau mengetahui kecepatan kerja operator dikenal dengan "Performance Ratting (PR)".

Penyesuaian menurut Westinghouse

$$
\begin{array}{lll}
\text { Keterampilan } & : \operatorname{good}(\mathrm{C} 1) & =+0.06 \\
\text { Usaha } & : \text { Good }(\mathrm{C} 2) & =+0,02 \\
\text { Kondisi Kerja } & : \text { Averaage }(\mathrm{D}) & =+0 \\
\text { Konsistensi } & : \operatorname{good}(\mathrm{C}) & =+0,01 \\
\text { Total } & & =+0,09
\end{array}
$$

\section{Menghitung Waktu Baku}

Waktu baku merupakan waktu yang digunakan sebagai patokan dalam menyelesaikan suatu operasi kerja. Waktu yang akan digunakan harus mencakup semua elemen-elemen kerja dan ditambah dengan kelonggaran-kelonggaran (allowance) yang perlu, sehingga waktu baku diperoleh dengan menjumlahkan waktu normal dengan perkalian antara waktu normal dan allowance.
Tabel 4.6. Hasil perhitungan waktu siklus, waktu normal, dan waktu baku

\begin{tabular}{cccccc}
\hline $\begin{array}{c}\text { No. } \\
\text { Ope } \\
\text { rasi }\end{array}$ & $\begin{array}{c}\text { Waktu } \\
\text { Siklus } \\
\text { (Detik) }\end{array}$ & $P$ & $\begin{array}{c}\text { Waktu } \\
\text { Normal } \\
\text { (Detik) }\end{array}$ & A & $\begin{array}{c}\text { Waktu } \\
\text { Baku } \\
\text { (Detik) }\end{array}$ \\
\hline $0-1$ & 42.8 & 1.09 & 46.66 & $15 \%$ & 47.81 \\
$0-2$ & 23.9 & 1.13 & 27 & $17 \%$ & 28.17 \\
$0-3$ & 36.45 & 1.13 & 41.19 & $17 \%$ & 42.36 \\
$0-4$ & 37.2 & 1.13 & 42.03 & $17 \%$ & 43.2 \\
$0-5$ & 144.5 & 1.13 & 163.28 & $17 \%$ & 164.45 \\
$0-6$ & 8.14 & 1.13 & 9.2 & $17 \%$ & 10.37 \\
$0-7$ & 3.96 & 1.13 & 4.47 & $17 \%$ & 5.64 \\
$0-8$ & 6.41 & 1.13 & 7.24 & $17 \%$ & 8.41 \\
$0-9$ & 12.4 & 1.13 & 14.01 & $17 \%$ & 15.18 \\
$0-10$ & 6.34 & 1.13 & 7.16 & $17 \%$ & 8.33 \\
$0-11$ & 5.97 & 1.13 & 6.75 & $17 \%$ & 7.92 \\
$0-12$ & 4.35 & 1.13 & 4.91 & $17 \%$ & 5.52 \\
$0-13$ & 11.71 & 1.13 & 13.23 & $17 \%$ & 14.4 \\
$0-14$ & 7.26 & 1.13 & 8.2 & $17 \%$ & 9.37 \\
$0-15$ & 3.09 & 1.13 & 3.49 & $17 \%$ & 4.46 \\
$0-16$ & 1.91 & 1.13 & 2.15 & $17 \%$ & 3.32 \\
& & & & & 418.91 \\
\hline
\end{tabular}

Tabel 4.7 pembagian operasi stasiun kerja kondisi awal

\begin{tabular}{cccc}
\hline $\begin{array}{c}\text { Stasiun } \\
\text { Kerja }\end{array}$ & $\begin{array}{c}\text { Operasi } \\
\text { Kerja }\end{array}$ & $\begin{array}{c}\text { Waktu Baku } \\
\text { (detik) }\end{array}$ & $\begin{array}{c}\text { Total Waktu } \\
\text { (detik) }\end{array}$ \\
\hline 1 & $0-1$ & 24.98 & 24.98 \\
2 & $0-2$ & 28.17 & 113.73 \\
& $0-3$ & 42.36 & \\
& $0-4$ & 43.2 & \\
3 & $0-5$ & 164.45 & 164.45 \\
4 & $0-6$ & 10.37 & 24.42 \\
& $0-7$ & 5.64 & \\
& $0-8$ & 8.41 & \\
5 & $0-9$ & 15.18 & 15.18 \\
6 & $0-10$ & 8.33 & 16.25 \\
& $0-11$ & 7.92 & \\
7 & $0-12$ & 5.52 & 5.52 \\
8 & $0-13$ & 14.4 & 14.4 \\
9 & $0-14$ & 9.37 & 17.15 \\
& $0-15$ & 4.46 & \\
& $0-16$ & 3.32 & \\
& & & 396.08 \\
\hline
\end{tabular}

Tabel 4.8 Prioritas pembebanan di tiap wilayah berdasarkan waktu operasi kondisi awal

\begin{tabular}{clc}
\hline $\begin{array}{c}\text { Wilayah } \\
\text { (Stasiun } \\
\text { Kerja) }\end{array}$ & $\begin{array}{l}\text { Prioritas } \\
\text { Operasi }\end{array}$ & $\begin{array}{c}\text { Waktu Kerja } \\
\text { (Detik) }\end{array}$ \\
\hline 1 & $0-1$, & 47.81 \\
2 & $0-4,0-3,0-2$, & 113.73 \\
3 & $0-5$, & 164.45 \\
4 & $0-6,0-8,0-7$, & 24.42 \\
5 & $0-9$, & 15.18 \\
6 & $0-10,0-11$, & 16.25 \\
7 & $0-12$ & 5.52 \\
8 & $0-13$ & 14.4 \\
9 & $0-14,0-15,0-16$ & 17.15 \\
\hline
\end{tabular}


Tabel 4.9 Prioritas pembebanan di tiap wilayah berdasarkan waktu operasi kondisi usulan

\begin{tabular}{clc}
\hline $\begin{array}{c}\text { Wilayah } \\
\text { (Stasiun } \\
\text { Kerja) }\end{array}$ & $\begin{array}{l}\text { Prioritas } \\
\text { Operasi }\end{array}$ & $\begin{array}{c}\text { Waktu } \\
\text { Kerja } \\
\text { (detik) }\end{array}$ \\
\hline 1 & $0-1$, & 47.81 \\
2 & $0-4,0-3,0-2$, & 113.73 \\
3 & $0-6,0-8,0-7$, & 24.42 \\
4 & $0-9$, & 15.18 \\
5 & $0-10,0-11$, & 16.25 \\
6 & $0-13,0-12$ & 19.92 \\
7 & $0-14,0-15,0-16$ & 17.15 \\
\hline
\end{tabular}

Tabel 4.10 Pengelompokkan operasi berdasarkan pendekatan wilayah

\begin{tabular}{|c|c|c|c|}
\hline $\begin{array}{c}\text { Stasi } \\
\text { un } \\
\text { kerja }\end{array}$ & Operasi & Waktu Operasi & Effisiensi\% \\
\hline 1 & $0-1$, & 47,81 & $\frac{47.81}{113.73} \times 100=42.04$ \\
\hline 2 & $\begin{array}{c}0-4,0-3,0- \\
2\end{array}$ & $\begin{array}{c}43.2+42.36+28 \\
17=113.73\end{array}$ & $\frac{113.73}{113.73} \times 100=100$ \\
\hline 3 & $\begin{array}{l}0-6,0-8,0- \\
7,\end{array}$ & $\begin{array}{c}10.37+8.41+5.6 \\
4=24.42\end{array}$ & $\frac{24.42}{113.73} x 100=21.47$ \\
\hline 4 & $0-9$ & 15.18 & $\frac{15.18}{113.73} \times 100=13.34$ \\
\hline 5 & $0-10,0-11$ & $\begin{array}{l}8.33+7.92= \\
16.25\end{array}$ & $\frac{16.25}{113.73} \times 100=14.28$ \\
\hline 6 & $0-13,0-12$ & $\begin{array}{l}5.52+14.4= \\
19.92\end{array}$ & $\frac{19.92}{113.73} \times 100=17.51$ \\
\hline 7 & $\begin{array}{c}0-14,0-15 \\
0-16\end{array}$ & $\begin{array}{c}9.37+4.46+ \\
3.32=17.15\end{array}$ & $\frac{17.15}{113.73} \times 100=15.38$ \\
\hline \multicolumn{3}{|c|}{$\begin{array}{l}\text { Efisiensi rata-rata lintas } \\
\text { keseluruhan }\end{array}$} & $32.29 \%$ \\
\hline
\end{tabular}

Tabel 4.11 perbandingan lintas produksi awal dan setelal perbaikan

\begin{tabular}{lccc}
\hline \multicolumn{1}{c}{ Perbandingan } & $\begin{array}{c}\text { Kondisi } \\
\text { Awal }\end{array}$ & $\begin{array}{c}\text { Kondisi } \\
\text { Perbaikan }\end{array}$ & $\begin{array}{c}\text { Effisiensi } \\
\text { Perusahaan }\end{array}$ \\
\hline $\begin{array}{l}\text { Jumlah Stasiun } \\
\text { Kerja }\end{array}$ & 9 & 7 & 2 \\
$\begin{array}{l}\text { Waktu Operasi } \\
\text { Terlama (Detik) }\end{array}$ & 164.45 & 113.73 & 50.72 \\
$\begin{array}{l}\text { Kapasitas } \\
\text { Produksi }\end{array}$ & $\begin{array}{c}218 \\
\text { box/hari }\end{array}$ & $\begin{array}{c}295 \\
\text { box/hari }\end{array}$ & $35.00 \%$ \\
Balance Delay & 73.23 & 57.69 & $15.54 \%$ \\
Efisiensi Lintasan & $26.50 \%$ & $42.31 \%$ & $15.81 \%$ \\
\hline
\end{tabular}

\section{SIMPULAN}

Dari hasil perhitungan dapat disimpulkan sebagai berikut :

Jumlah stasiun kerja pada kondisi awal berjumlah 9 stasiun kerja, setelah dilakukan perbaikan menjadi 7 stasiun kerja sehingga perusahaan mendapatkan effisiensi sebesar 2 stasiun kerja.

Waktu operasi kerja terlama dalam stasiun kerja sebesar 164,45 detik, setelah dilakukan perbaikan waktu operasi kerja terlama menjadi 113,73 detik, perusahaan mendapatka effisiensi sebesar 50,72 detik.

Kapasitas produksi mengalami peningkatan dari 218 box/hari menjadi 295 box/hari setelah adanya perbaikan, perusahaan mendapatkan effisiensi sebesar 35\%.

Balance delay pada proses awal sebelum perbaikan sebesar 73,23\% setelah dilakukan perbaikan menjadi sebesar $57,69 \%$, perusahaan mendapatkan effisiensi sebesar 15,54\%.

Effisiensi lintasan pada kondisi awal sebesar $26,50 \%$ setelah adanya perbaikan menjadi $42,31 \%$, perusahaan memperoleh effisiensi sebesar $15,81 \%$

\section{DAFTAR PUSTAKA}

Apple, James, M, 1990, “Tata Letak Pabrik dan Pemindahan Bahan” Edisi Ketiga, ITB, Bandung.

Baroto, Teguh, 2002, "Perencanaan dan Pengendalian Produksi", Penerbit Ghalian Indonesia, Jakarta.

Nasution, H, A, 1999, "Perancangan dan Pengendalian Produksi”, Jurusan Teknik Industri, ITS, Surabaya.

Purnomo, Hari, 2004, "Pengantar Teknik Industri" Edisi Kedua, Penerbit Ghara Ilmu, Yogyakarta.

Sumayang, Lalu, 2003, "Dasar-dasar Manajemen Produksi dan Operasi" Edisi Pertama, Penerbit Salemba Empat, Jakarta.

Sutalaksana, 2006, "Teknik Tata Cara Kerja", Jurusan Teknik Industri, ITB, Bandung.

Wignjosoebroto, S, 1995, "Ergonomi : Studi Gerak dan Waktu" Edisi Pertama, ITS, Penerbit Guna Widya, Jakarta. 
Wignjosoebroto, S, 2003, "Pengantar Teknik dan Manejemen Industri” Edisi Pertama, ITS, Penerbit Guna Widya, Jakarta.

Wignjosoebroto, S, 1992, "Teknik Tata Cara dan Pengukuran Kerja" Edisi Kedua, ITS, Penerbit Guna Widya, Jakarta. 